Int. J. Electrochem. Sci., 12 (2017) $8477-8494$

International Journal of

ELECTROCHEMICAL

SCIENCE

www.electrochemsci.org

\title{
Gelatin-zirconium Dioxide Nanocomposite as a Ni (II) Selective Potentiometric Sensor: Heavy Metal Separation and Photocatalysis
}

\author{
Deepak Pathania ${ }^{1, *}$, Manita Thakur ${ }^{1}$, Shefali Jasrotia ${ }^{1}$, Shilpi Agarwal ${ }^{2}$ and Vinod Kumar Gupta, ${ }^{2, *}$ \\ ${ }^{1}$ School of Chemistry, Shoolini University, Solan 173212, Himachal Pradesh, India \\ ${ }^{2}$ Applied Chemistry Department, University of Johannesburg, Doornfontein Campus, Johannesburg, \\ South Africa \\ *E-mail: dpathania74@gmail.com; vinodfc@gmail.com
}

doi: $10.20964 / 2017.09 .49$

Received: 16 May 2017 / Accepted: 10 July 2017 / Published: 13 August 2017

The present work represents the synthesis of gelatin-zirconium dioxide nanocomposite (GT/ZONC) ion exchanger by sol-gel method. GT/ZONC was characterised by various techniques such as FTIR, XRD, SEM and TEM. To understand the ion-exchange capabilities of the material different physicochemical properties such as effect of eluent concentration, elution behaviour, thermal stability, $\mathrm{pH}$ titration and distribution coefficient were studied. XRD pattern confirms the semi crystalline nature of nanocomposite with low intensity peaks. TEM results confirmed the formation of material in the nano-range with particle size of $36 \mathrm{~nm}$. $\mathrm{pH}$ titration studied showed the monofunctional nature of the material. The distribution coefficient results revealed that the GT/ZONC was highly selective for Ni (II) ions. Some binary separation of metal ion pairs such as $\mathrm{Ni}^{2+}-\mathrm{Zn}^{2+}, \mathrm{Cu}^{2+}-\mathrm{Al}^{3+}, \mathrm{Pb}^{2+}-\mathrm{Cu}^{2+}, \mathrm{Co}^{2+}$ $-\mathrm{Ni}^{2+}, \mathrm{Cd}^{2+}-\mathrm{Pb}^{2+}, \mathrm{Mg}^{2+}-\mathrm{Cd}^{2+}, \mathrm{Zn}^{2+}-\mathrm{Mg}^{2+}, \mathrm{Co}^{2+}-\mathrm{Al}^{3+}$ were accomplished onto GT/ZONC column. GT/ZONC was investigated for the photocatalytic degradation of methylene blue and degraded $82 \%$ of MB within 5 hrs of solar irradiation. Ni (II) ion selective membrane electrode was fabricated with a quick time response and wide $\mathrm{pH}$ working range.

Keywords: Gelatin, zirconium dioxide, nanocomposite, ion selective electrode, heavy metals, methylene blue

\section{FULL TEXT}

(C) 2017 The Authors. Published by ESG (www.electrochemsci.org). This article is an open access article distributed under the terms and conditions of the Creative Commons Attribution license (http://creativecommons.org/licenses/by/4.0/). 